Nowoczesne Systemy Zarządzania

Zeszyt 13 (2018), nr 4 (październik-grudzień)

ISSN 1896-9380, s. 145-158

Modern Management Systems

Volume 13 (2018), No. 4 (October-December)

ISSN 1896-9380, pp. 145-158
Instytut Organizacji i Zarządzania

Wydział Cybernetyki

Wojskowa Akademia Techniczna

w Warszawie

Institute of Organization and Management

Faculty of Cybernetics

Military University of Technology

\title{
Mechanizm komunikacji Universal Data Exchange Interface w procesie wymiany danych pomiędzy systemami ExpertWMS $₫$ i ERP
}

\section{The Universal Data Exchange Interface communication mechanism in the process of data exchange between ExpertWMS ${ }^{\circledR}$ and ERP systems}

\author{
Monika Łobaziewicz \\ DataConsult Sp. z o.o.
}

\begin{abstract}
Abstrakt. Celem artykułu jest prezentacja wyników prac rozwojowych dotyczących systemu DataConnect z zastosowaniem mechanizmu komunikacji Universal Data Exchange Interface dla modelu wymiany informacji pomiędzy systemem ExpertWMS ${ }$, a systemami zewnętrznymi ERP. Prace rozwojowe były ostatnim etapem badań nad stworzeniem odpornego na zaburzenia elektromagnetyczne prototypu systemu punktów pomiarowych przy gniazdach produkcyjnych opartego o technologię selektywnej bramki RFID. W artykule zaprezentowano zarówno teoretyczne, jak i praktyczne podejście do problematyki wymiany danych i komunikacji w przedsiębiorstwach przemysłowych, które w zarządzaniu wykorzystują złożone systemy informatyczne wspomagające procesy produkcyjne, logistyczne i biznesowe.
\end{abstract}

Słowa kluczowe: wymiana danych, system zarządzania magazynem, ERP, system komunikacji danych.

Abstract. The aim of this article is to present the results of development work on DataConnect system using the Universal Data Exchange Interface (UDEI) for the information exchange model between ExpertWMS ${ }^{\circledR}$ and external ERP systems. The development work was the final step of research conducted to the resistant on electromagnetic disturbances system based on the selective RFID gate technology. The article presents both a theoretical and practical approach to data exchange and communication in industrial enterprises using complex IT systems to support production, logistics and business processes.

Keywords: Data Exchange, Warehouse Management System, ERP, Data connection. 


\section{Wstęp}

Rozwiązania informatyczne zapewniające wymianę danych w procesach produkcyjnych, logistycznych oraz biznesowych podlegają stałemu doskonaleniu $\mathrm{z}$ uwagi na szybki przyrost danych, które są gromadzone w różnych formatach i bazach danych (Moris, 2016, s. 8-10). W przedsiębiorstwach przemysłowych dochodzi dodatkowy problem wynikający z działania w systemie produkcyjnym i logistyki magazynowej wielu rozporoszonych i autonomicznych jednostek automatyki przemysłowej, z których każda działa w oparciu o własne - wbudowane systemy lub aplikacje oraz emituje fale elektromagnetyczne zakłócające prawidłowość transferu danych. Proces wymiany danych wymaga, aby dane były ustrukturyzowane i wystandaryzowane dla potrzeb ich transferu $z$ jednego systemu do drugiego, które działają w ramach intralogistyki przedsiębiorstwa. Dzisiejsze uwarunkowania gospodarcze przyczyniły się do tego, że organizacjom zależy, aby wymiana danych odbywała się płynnie w czasie rzeczywistym. W związku $\mathrm{z}$ tym proces automatyzacji wymiany danych ma przebiegać w sposób niezawodny i bezpieczny (Tyagi, 2017), (Ning, 2012, s. 441-450).

Badania przeprowadzone przez DataConsult Sp. z o.o. (DataConsult, 2013) korespondują z powyższymi przesłankami. Okazuje się, że integracja danych systemów wbudowanych w urządzenia automatyki przemysłowej (bramki, czytniki), rozwiązania mobilne (terminale, kolektory danych), oraz systemy zarządzania przedsiębiorstwem, determinuje konieczność optymalizacji procesów produkcyjnych, logistycznych i biznesowych. Wymogi stawiane tym systemom to przede wszystkim zsynchronizowana komunikacja zapewniająca płynną wymianę danych, która ma gwarantować niezawodność ich funkcjonowania w trudnych warunkach produkcyjnych.

Celem artykułu jest prezentacja wyników prac rozwojowych dotyczących systemu DataConnect, dla którego opracowano mechanizm Universal Data Exchange Interface (UDEI) zapewniający wymianę danych pomiędzy systemem ExpertWMS ${ }^{\circledast}$ a dowolnym systemem zewnętrznym ERP. Prace rozwojowe były ostatnim etapem badań nad stworzeniem odpornego na zaburzenia elektromagnetyczne prototypu systemu punktów pomiarowych przy gniazdach produkcyjnych opartego o technologię selektywnej bramki RFID.

Artykuł składa się z kilku części, z których pierwsza prezentuje przegląd literatury przedmiotu, druga metodologię badań, trzecia koncepcję i sposób działania mechanizmu UDEI w systemie DataConnect. Na koniec przedstawiono wnioski $\mathrm{z}$ badań oraz podsumowanie. 


\section{Wymiana danych w systemie produkcji i logistyki magazynowej}

W literaturze można znaleźć wiele publikacji poświęconych tematyce synchronizacji i przesyłania danych pomiędzy systemami wspomagającymi realizację procesów produkcyjnych i magazynowych, zarówno na poziomie przedsiębiorstwa, jak i wewnętrznego łańcucha dostaw (Brdulak, 2012, s. 17), (Jurga et al., 2011, s. 30-31), (Tundys et al., 2010, s. 115-116), (Ronanki et al., 2016), (Dhanda et al., 2016). Główne problemy, jakie podejmują autorzy, dotyczą przyczyn zakłóceń w komunikacji między systemami, opóźnień transferu danych i źródeł ich zniekształcania, optymalizacji procesów wymiany, zarządzania danymi w środowisku rozporoszonym, wielosystemowym, o wielu bazach danych, standardów, czy też narzędzi integracji i wymiany danych.

Współczesne systemy zarządzania procesami produkcji i logistyki magazynowej realizowane są w oparciu o tzw. model warstwowy automatyzacji przedsiębiorstwa (Fowler, 2005), (Klonowski, 2004), w którym występują poziomy typu hardware i software. W modelu tym, decyzje dotyczące zleceń produkcyjnych oraz jakości produktów podejmowane są na poziomie warstwy zarządzania, natomiast w kolejnych niższych warstwach: sterowania i procesu produkcji, przetwarzane są na decyzje operacyjne. W związku z różnymi funkcjami, jakie pełnią poszczególne warstwy w przedmiotowym modelu, rozwiązania sieciowe (serwery, Ethernet) występujące na ich poziomach muszą spełniać odpowiednie wymagania transmisyjne (Kwiecień, 2012).

Drugi ważny aspekt w modelu to warstwa oprogramowania, która jest bardzo zróżnicowana, ponieważ przedsiębiorstwa przemysłowe nie korzystają z jednolitego software'u na poziomach strategicznym, operacyjnym i bazodanowym. Integracja danych wymaga zatem dodatkowych działań umożliwiających sprawny import i eksport danych, które będą konwertowane za pomocą dedykowanych mechanizmów informatycznych, co ma istotne znaczenie dla prawidłowej realizacji procesów produkcyjnych i logistycznych oraz informacyjnych (Tyagi, Watanabe, 2017). W celach integracji danych generowanych przez centra obróbcze, maszyny i urządzenia na linii produkcyjnej oraz logistyki magazynowej stosuje się najczęściej następujący model (Doan et al., 2015, s. 9-12):

- stworzenie jednej hurtowni danych dla wszystkich procesów wytwarzania i logistyki;

- konsolidacja lub migracja bibliotek dokumentów pochodzących z poszczególnych jednostek infrastruktury produkcyjnej i magazynowej, realizujących procesy do hurtowni danych;

- stworzenie oprogramowania zapewniającego zintegrowaną komunikację i wymianę danych między jednostkami infrastruktury produkcyjnej i magazynowej a systemem zewnętrznym wspierającym procesy biznesowe typu ERP;

- przetworzenie danych w systemie zewnętrznym ERP;

- eksport danych do systemów wspierających realizację procesów produkcyjnych, logistycznych. 
Istnieją dwa główne standardy wykorzystywane w komunikacji danych (Ning, 2012, s. 441-450). Pierwszy opiera się na łączu typu „punkt-punkt” (ang. point-to-point connection). Wymaga znajomości wielu parametrów, w tym adresów na obydwu końcach łącza, algorytmów kompresji, protokołów uwierzytelnienia, czasem adresów serwerów DNS (Yang et al., 2006, s. 1026-1036), (Wing, 2007), (Linthicum, 2001), (Bussler, 2003, s. 6-10), dlatego najczęściej sprawdza się w konsolidacji danych na poziomie hurtowni danych. Drugi standard typu „gwiazda” (ang. star connection) zapewnia wymianę danych pomiędzy wieloma niezależnymi, heterogenicznymi urządzeniami i aplikacjami z wykorzystaniem sieci Internet (Nicolescu et al., 2006, s. 260-275). Obecnie przedsiębiorstwa produkcyjne potrzebują wysokowydajnych technologicznie rozwiązań informatycznych, dlatego niezmiernie ważne jest zaprojektowanie takich, które z jednej strony będą efektywne pod względem bazodanowym i serwerowym, a $z$ drugiej strony oprogramowania zapewniającego automatyczną komunikację danych (Arenas, 2010).

\section{Metodologia badań}

Badania przeprowadzone przez DataConsult Sp. z o.o. na grupie $\mathrm{N}=90$ przedsiębiorstw z sektora przemysłowego w Polsce, wykazały że 53,3\% przedsiębiorstw produkcyjnych wykorzystuje maszyny i urządzenia, które istotnie zakłócają transmisję danych. W efekcie w 22,2\% przypadków nie udało się wdrożyć skutecznie systemów informatycznych. Głównym powodem okazały się zaburzenia elektromagnetyczne, które powodują zakłócenia ciągłości przepływu danych i błędną identyfikację poszczególnych jednostek produktów, surowców i mają negatywny wpływ na międzyoperacyjną oraz końcową kontrolę jakości procesu. Przedsiębiorstwa wskazały następujące oczekiwania: zwiększona odporność pracy systemu produkcyjnego na zaburzenia elektromagnetyczne (81\%), zwiększenie niezawodności jednoznacznej identyfikacji surowców, materiałów, produktów (80\%), możliwość dostosowania nowych rozwiązań systemowych do już istniejących w zakładzie produkcyjnym (79\%), pełna integracja $\mathrm{z}$ zewnętrznymi systemami informatycznymi oraz urządzeniami automatyki przemysłowej (77\%), skalowalność rozwiązania (71\%), możliwość zmniejszenia odstępu pomiędzy liniami produkcyjnymi bez ryzyka sczytania elementu z sąsiedniej linii (65\%), możliwość dowolnego zagęszczenia punktów pomiarowych w ramach linii produkcyjnej (57\%).

Rezultaty badań stały się inspiracją do poszukiwań skutecznego rozwiązania problemów, stąd celem głównym projektu było stworzenie odpornego na zaburzenia elektromagnetyczne systemu punktów pomiarowych z wykorzystaniem innowacyjnej technologii selektywnej bramki RFID, a następnie jego implementacja w warunkach rzeczywistych w oparciu o prace $\mathrm{B}+\mathrm{R}$. 
W ramach projektu zrealizowano 6 zadań na etapie badań przemysłowych i prace rozwojowe, dzięki którym została zdobyta wiedza na temat fizyki fal elektromagnetycznych, przeanalizowano możliwości ograniczenia wpływu zaburzeń elektromagnetycznych na urządzenia elektroniczne, zaprojektowano algorytmy gromadzenia, przetwarzania danych oraz ich prezentacji do zastosowania w prototypie systemu, opracowano algorytmy modelowania procesów, rozliczania surowców, śledzenia ich przepływu (ang. Traceability), kontroli jakości oraz analizy wydajnościowe, zasobowe i optymalizacyjne, stworzono prototyp interfejsu punktu pomiarowego przy gnieździe produkcyjnym oraz prototyp modułu komunikacji. Następnie określono warunki jego skalowalności na linii produkcyjnej.

W rezultacie został stworzony system (rys. 1) składający się ze zintegrowanych ze sobą elementów:

1. Selektywna bramka RFID - urządzenie odczytujące informacje z tagów RFID przechodzących jedynie przez światło bramki.

2. Stanowiska pomiarowe - zestaw czujników przemysłowych umożliwiających wykrywanie obecności, pomiar koloru, wagi.

3. Komputer przemysłowy z ekranem dotykowym, oraz mobilne punkty kontroli na kolektorach danych.

4. Programator RFID - urządzenie służące do zapisu danych w transponderach RFID.

5. Ekrany pochłaniające fale elektromagnetyczne emitowane przez urządzenia produkcyjne.

6. System informatyczny umożliwiający zarządzanie punktami pomiarowymi oraz modelowanie procesów realizowanych przez gniazda produkcyjne.

7. Infrastruktura sieciowa zapewniająca łączność pomiędzy modułami systemu.

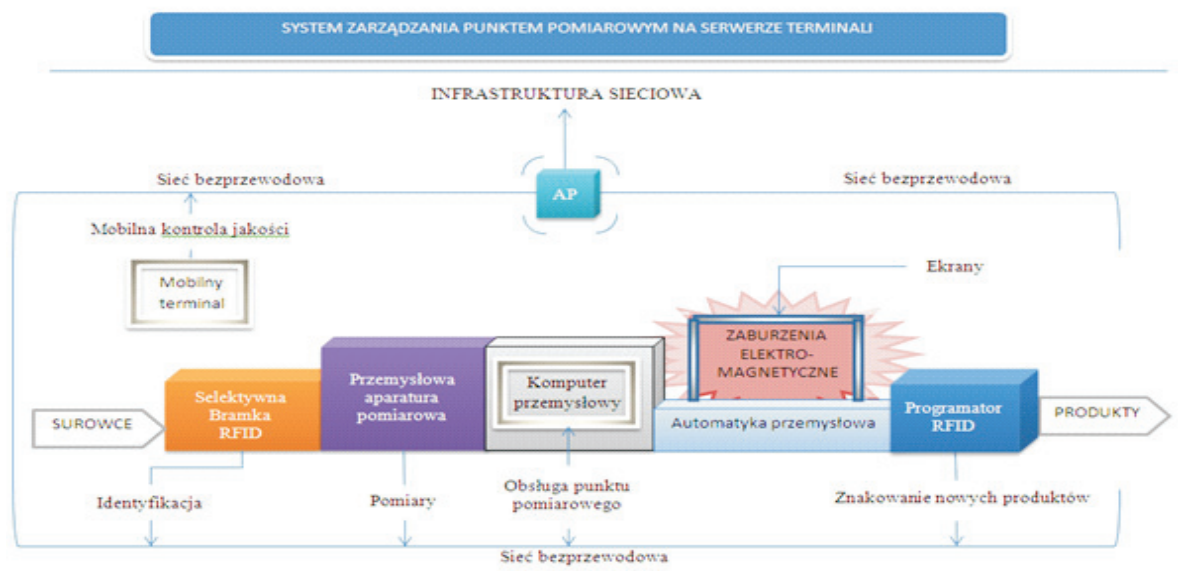

Rys. 1. Prototyp odpornego na zaburzenia elektromagnetyczne systemu punktów pomiarowych z wykorzystaniem innowacyjnej technologii selektywnej bramki RFID

Źródło: Raport z badań, DataConsult Sp. z o.o., Kraków, 2013 
Dotychczasowe wyniki badań zostały zaprezentowane w kilku artykułach (Łobaziewicz et al., 2013, s. 84-96), (Łobaziewicz et al., 2014, s. 39-42), (Maćkowiak et al., 2014a, s. 4633-4639), (Maćkowiak et al., 2014b), (Łobaziewicz, 2017, s. 377-385). Niniejszy artykuł jest kontynuacją cyklu. Przedstawia rezultaty realizacji ostatniego celu szczegółowego zdefiniowanego w badaniach rozwojowych pn. „Określenie szczegółowych parametrów systemu oraz modeli wymiany informacji pomiędzy jego modułami wraz z uwzględnieniem aplikacji zewnętrznych". Ze względu na obszerność badań i ochronę kodów w artykule pominięto omówienie parametrów technicznych warstwy bazodanowej oraz procedury opisujące algorytmy programistyczne.

\section{Koncepcja mechanizmu wymiany danych UDEI w systemie DataConnect}

Niniejszy fragment prezentuje część wyników prac rozwojowych, które dotyczą procesów importu oraz eksportu danych mechanizmu UDEI systemu DataConnect. $\mathrm{W}$ tym celu w pierwszej kolejności zaprezentowano model systemu, a następnie elementy mechanizmu wymiany danych, zapewniające ich przepływ pomiędzy systemem ExpertWMS ${ }^{\circledast}$ i dowolnym, zewnętrznym ERP.

\subsection{DataConnect jako narzędzie komunikacji pomiędzy systemami ExpertWMS ${ }^{\circledast}$ i zewnętrznym klasy ERP}

Jednym z elementów odpornego na zaburzenia elektromagnetyczne prototypu systemu punktów pomiarowych przy gniazdach produkcyjnych, opartego o technologię selektywnej bramki RFID, jest autorski system ExpertWMS ${ }^{\circledR}$ firmy DataConsult, który może być integrowany $\mathrm{z}$ więcej niż jednym systemem zewnętrznym ERP. W ramach projektu, na etapie prac rozwojowych, przeprowadzono analizę możliwości jego integracji z używanymi przez przedsiębiorstwa produkcyjne różnymi systemami ERP, a następnie zaprojektowano parametry i procedury informatyczne, które należy zastosować w systemie DataConnect. Prace rozwojowe doprowadzily do opracowania uniwersalnych mechanizmów jego integracji, co zostało omówione poniżej.

System DataConnect to program systemu ExpertWMS ${ }^{\circledR}$ odpowiedzialny za automatyczną komunikację pomiędzy bazą systemu a bazami zewnętrznych systemów ERP. Oprócz mechanizmów integracji, posiada mechanizmy kontroli spójności danych, możliwość konfiguracji kanałów komunikacyjnych, zarządczych oraz informacji wymaganych do komunikacji z wybranym systemem ERP. Składa się z kilku podsystemów, które umożliwiają transformowanie danych w taki sposób, że są one przekształcane do formatu zrozumiałego dla odpowiedniego systemu, a następnie przy pomocy narzędzi komunikacji przesyłane do systemu zewnętrznego ERP. Dotychczas system DataConnect posiadał jeden mechanizm komunikacji 
Dedicated Data Exchange Interface (DDEI), który zapewnia automatyczny import/ export danych do dedykowanego systemu zewnętrznego ERP, tj. CDNXL, Optima, Simple i DHL. W wyniku prac rozwojowych opracowany został drugi mechanizm komunikacji Universal Data Exchange Interface (UDEI). Jego celem jest zapewnienie automatycznego importu/exportu danych najpierw do systemu wirtualnego, skąd może nastąpić ich eksport z systemu ExpertWMS ${ }^{\circledR}$ do dowolnego systemu ERP dzięki zdefiniowanym regułom. W porównaniu do DDEI nie wykrywa naruszeń oraz nie jest w stanie kontrolować zgodności obiektów, jakie obsługuje.

Na rysunku 2 przedstawiono udoskonalony model działania komunikacji pomiędzy systemem ExpertWMS ${ }^{\circledR}$ a systemami zewnętrznymi oparty na systemie DataConnect, który posiada obydwa mechanizmy komunikacji.

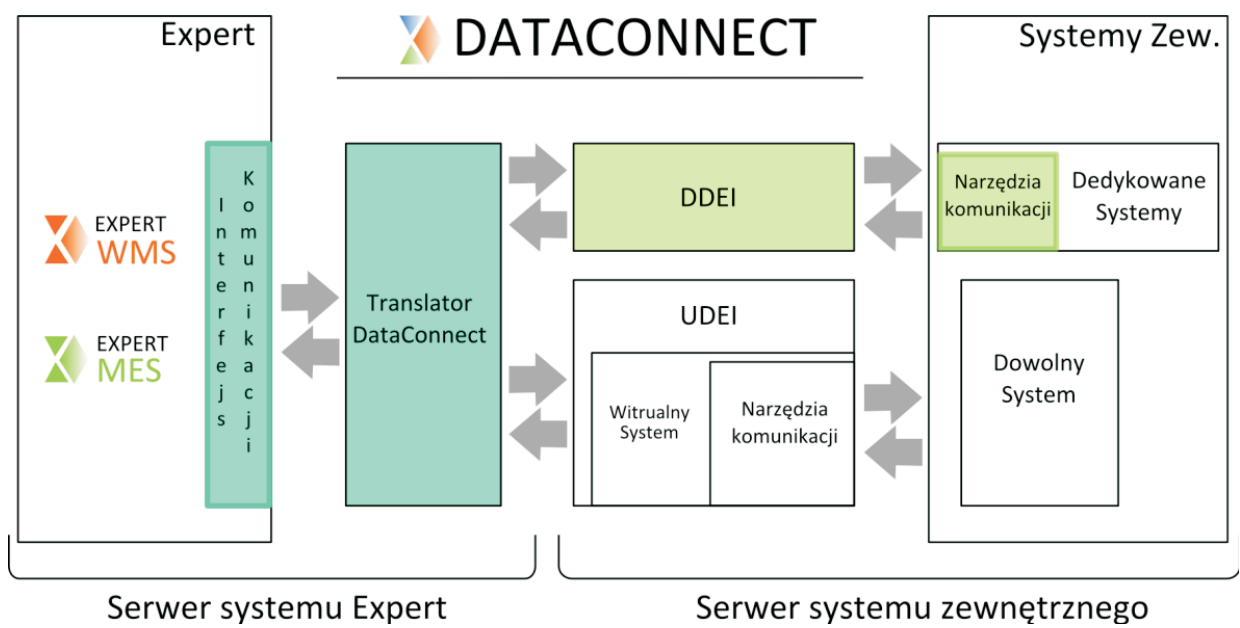

Rys. 2. Model systemu DataConnect

Źródło: DataConsult Sp. z o.o., 2014, Podręcznik integratora DataConnect UDEI, s. 6

Komunikacja w systemie DataConnect przebiega w kilku etapach. Pierwszy z nich realizowany jest zawsze na serwerze systemu ExpertWMS ${ }^{\oplus}$, skąd dane pobierane $\mathrm{z}$ bazy zostają przekształcone do standardowego formatu komunikacji zrozumiałego dla każdego z mechanizmów komunikacji DDEI i UEDI.

Biorąc pod uwagę cel artkułu, w dalszej części omawianego modelu skoncentrowano się na działaniu mechanizmu komunikacji UDEI.

$\mathrm{Na}$ drugim etapie sformatowane dane przesyłane są na serwer systemu zewnętrznego, gdzie trafiają do mechanizmu UDEI, który posiada wbudowany system wirtualny oraz narzędzia komunikacji. Dane są przesyłane pomiędzy nim a translatorem DataConnect i dalej systemem ExpertWMS ${ }^{\circledR}$ a systemem zewnętrznym przy wykorzystaniu dedykowanych narzędzi komunikacji. Na trzecim etapie administrator 
systemu powinien zdefiniować mechanizmy pobierania i zapisywania danych pomiędzy zewnętrznym systemem a wirtualnym systemem mechanizmu UDEI. Wszystkie wcześniejsze etapy komunikacji zachodzą automatycznie i posiadają mechanizmy sprawdzające poprawność komunikacji, dzięki czemu następuje przekazywanie pełnej informacji o zdarzeniach zachodzących w trakcie komunikacji pomiędzy systemem wirtualnym UDEI a systemem ExpertWMS ${ }^{\circledast}$. W trakcie konfiguracji informacje te mają również na celu ustalenie poprawnej komunikacji pomiędzy systemem ExpertWMS ${ }^{\oplus}$ a systemem zewnętrznym.

Badania przeprowadzone $\mathrm{w}$ ramach projektu wykazały, że poprawna obsługa zgłoszeń zdarzeń na etapie komunikacji pomiędzy UDEI a systemem ExpertWMS ${ }^{\circledast}$ powinna zostać uwzględniona podczas projektowania cyklicznych zadań komunikacji.

\subsection{Import danych do systemu ExpertWMS ${ }^{\circledR} \mathrm{w}$ mechanizmie UDEI}

W imporcie danych proces komunikacji między bazami danych wymaga zapewnienia bezpieczeństwa i spójności danych przenoszonych do tabeli przejściowej, stąd też przyjęto, że każdy obiekt typu:

- 'Magazyny', który oznacza lokalizacje w systemie ExpertWMS ${ }^{\circledR}$, czyli zapisane $\mathrm{w}$ bazie danych rekordy odpowiadające wszystkim położeniom towarów w fizycznym magazynie, w danej partii i jednostce logistycznej;

- 'Towary', przez który rozumie się zapisane w bazie danych rekordy odpowiadające wszystkim fizycznym towarom, które mogą być przedmiotem obrotu w magazynie;

- 'Kontrahenci', czyli zapisane w bazie danych rekordy zawierające informacje na temat dostawców lub odbiorców zasobów zgromadzonych w magazynie;

- 'Słowniki', które oznaczają w systemie ExpertWMS ${ }^{\circledast}$ obiekty statyczne, niewykonujące żadnych akcji. W danej chwili słowniki są zapisem danych odzwierciedlających aktualny stan magazynu;

- 'Polecenia' będące zbiorem danych zapisanych w tabelach, które odpowiadają dokumentom handlowym w magazynie użytkowanym przez operatora w celu wykonania czynności logistycznych; może być modyfikowany dwoma procedurami:

- dodanie/aktualizacja, która służy dodaniu nowych rekordów do danego obiektu lub aktualizacji już istniejących;

- usuwanie, która służy usunięciu wpisów z obiektów, których dana procedura dotyczy. Ze względów bezpieczeństwa założono, że użytkownik posiadający uprawnienia do pracy w systemie musi mieć świadomość usuwania już istniejących wpisów, dlatego przyjęto, że jeśli dany obiekt posiada zależne od niego inne obiekty, to procedura usuwania powoduje eliminację obiektu wraz z podrzędnie zależnymi od niego elementami.

Proces importu danych do systemu ExpertWMS ${ }^{\circledR}$ przedstawia rysunek 3. 
Dla poprawnego działania komunikacji z wirtualną bazą ERP założono, że standardowo każda procedura zawiera listę zmiennych wymaganych, czyli takich, które muszą pojawić się w zapytaniu i zmiennych opcjonalnych. Dla niektórych procedur przyjęto, że istnieją zmienne, z których należy wybrać tylko jedną z grupy.

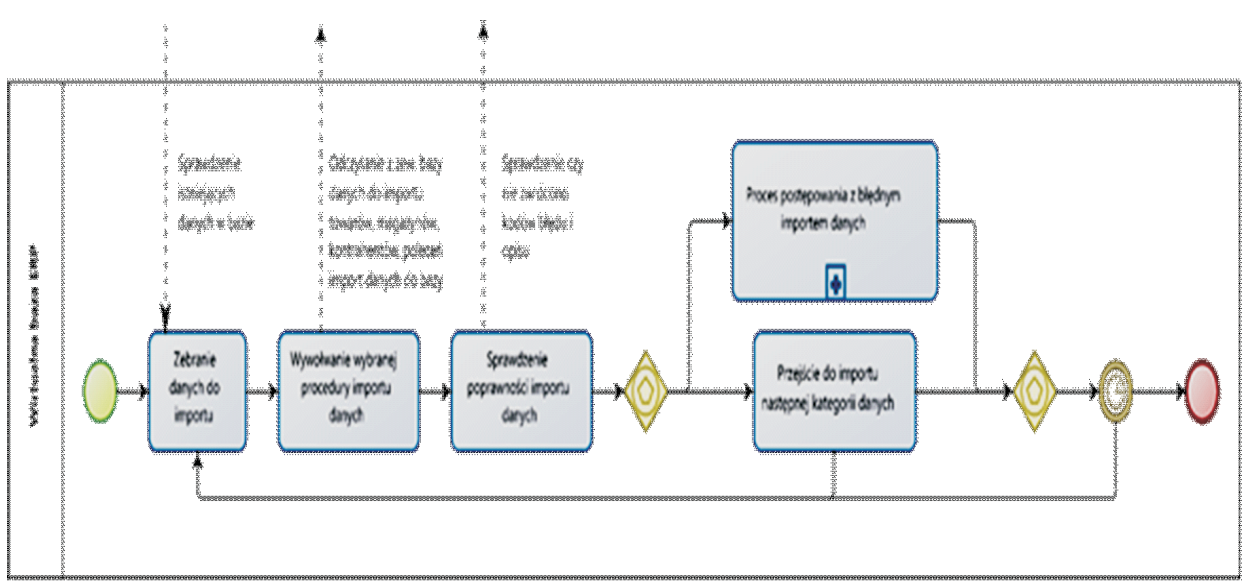

Rys. 3. Proces importu danych do systemu ExpertWMS ${ }^{\bullet}$

Źródło: DataConsult Sp. z o.o., 2014, Podręcznik integratora DataConnect UDEI, s. 13

Zaprojektowano, że import danych do systemu ExpertWMS ${ }^{\circledR}$ odbywa się w ustalonych sesjach czasowych w zależności od ilości danych wymienianych pomiędzy systemami, które mają wpływ na funkcjonowanie magazynu. W przypadku przerwy w imporcie nowych danych system działa poprawnie na podstawie wcześniej zaimportowanych zasobów, natomiast po wznowieniu komunikacji następuje ich uaktualnienie.

\subsection{Eksport danych z systemu ExpertWMS ${ }^{\circledast}$}

Poprawna komunikacja pomiędzy systemami wymaga aktualizacji zewnętrznego systemu ERP o zmiany wprowadzone przez operatorów w trakcie pracy na magazynie. $\mathrm{W}$ tym celu zdefiniowano procedury eksportu danych $\mathrm{z}$ systemu zgodne $\mathrm{z}$ procesem przedstawionym na rysunku 4.

Eksport danych w systemie ExpertWMS ${ }^{\circledR}$ do zewnętrznego systemu ERP wymaga stworzenia tzw. wirtualnego systemu ERP w oparciu o bazę danych, który będzie zawierał informacje na temat zmian, jakie zostały wykonane na towarach na podstawie dokumentów 'Polecenia', a które wcześniej zostały zaimportowane do systemu ExpertWMS ${ }^{\circledast}$. W tym celu wykonywana jest procedura 'dbo.wms_erp_realiznag_lista' dla dokumentów o statusie 'do wczytania'. Następnie z listy dokumentów zatwierdzonych realizacji zostaje zaczytany pierwszy z nich w oparciu o formułę 'najniższe@id'. 
Kontynuacja pracy wymaga użycia procedury 'wms_erp_polecnag_lista [@id]'. W wirtualnym systemie ERP zmieniany jest zewnętrzny status dokumentu na 'przetwarzanie' (@zew_status=P). Dalsze kroki postępowania opierają się o pętlę, w której najpierw następuje sprawdzenie, czy realizacja została zakończona i wprowadzone zmiany na towarach zostały zapisane w systemie ExpertWMS ${ }^{\circledR}$ w oparciu o formułę 'wms_erp_polecnag_lista [@id]warunek @dok_stan=2'. Jeśli czynność została zakończona, wówczas można przejść do dalszego etapu eksportu danych. W przeciwnym wypadku zewnętrzny status realizacji zostaje zamieniony na „Błąd” (@zew_status='E'), co oznacza, że zakończono eksport i następuje wybór kolejnego dokumentu przy zastosowaniu reguły 'następna_wartość@id'. Sprawdzenie, czy 'Polecenie', na podstawie którego została prawidłowo podjęta przez operatora systemu ExpertWMS ${ }^{\circledast}$ realizacja eksportu, następuje poprzez regułę 'wms_erp_realiznag_listawarunek@dok_status = $\{$ NULL,2,3,4\}?. Jeśli 'Polecenie’ zostało wykonane prawidłowo, wówczas eksport danych jest kontynuowany. Następnie z systemu ExpertWMS ${ }^{\circledast}$ zostaje zaczytana lista towarów, na których wykonano operacje o statusie 'w trakcie realizacji', przy użyciu formuły 'wms_erp_realizele_lista[@id]'. Lista ta powinna zostać zaimportowana do systemu ERP w celu wprowadzenia zmian na źródłowym dokumencie. Jeśli istnieje taka konieczność, to można w systemie zewnętrznym ERP lub na 'Poleceniu' w systemie ExpertWMS ${ }^{\circledR}$ porównać pozycje $\mathrm{z}$ realizacji z pozycjami dokumentów źródłowych w celu kontroli poprawności czynności przeprowadzonych przez pracownika. Po zakończeniu eksportu danych następuje w przejściowej bazie danych systemu ERP zamknięcie wykonywania pracy na wybranej realizacji oraz pomyślny eksport danych, co oznacza się statusem zewnętrznym 'wczytane' lub 'pominięte' w oparciu o regułę 'parametr', stosując formułę 'wms_erp_realiznag_zmienz wartości @zew_status = P', a następnie '@zew_status= $\{Z, O\}$ '. Po zakończeniu eksportu danych następuje przejście do realizacji o kolejnym numerze identyfikacyjnym „id”, który posiada status zewnętrzny 'do wczytania' (@zew_status='W') i przeprowadzany jest ponownie eksport danych według omówionego powyżej procesu. Ukończenie eksportu danych z ostatniej realizacji o statusie zewnętrznym ' $W$ ' oznacza wstrzymanie procesu sprawdzania realizacji dostępnych do eksportu dokumentów na z góry określony czas. Po jego upłynięciu ponownie rozpoczyna się sprawdzanie listy realizacji w celu wyszukania dokumentów o statusie zewnętrznym ' $W$ '. Jeśli procedura przeszukiwania zwróci dokumenty do wczytania, wówczas rozpoczyna się proces eksportu danych z bazy wirtualnej systemu ERP do systemu zewnętrznego ERP. 

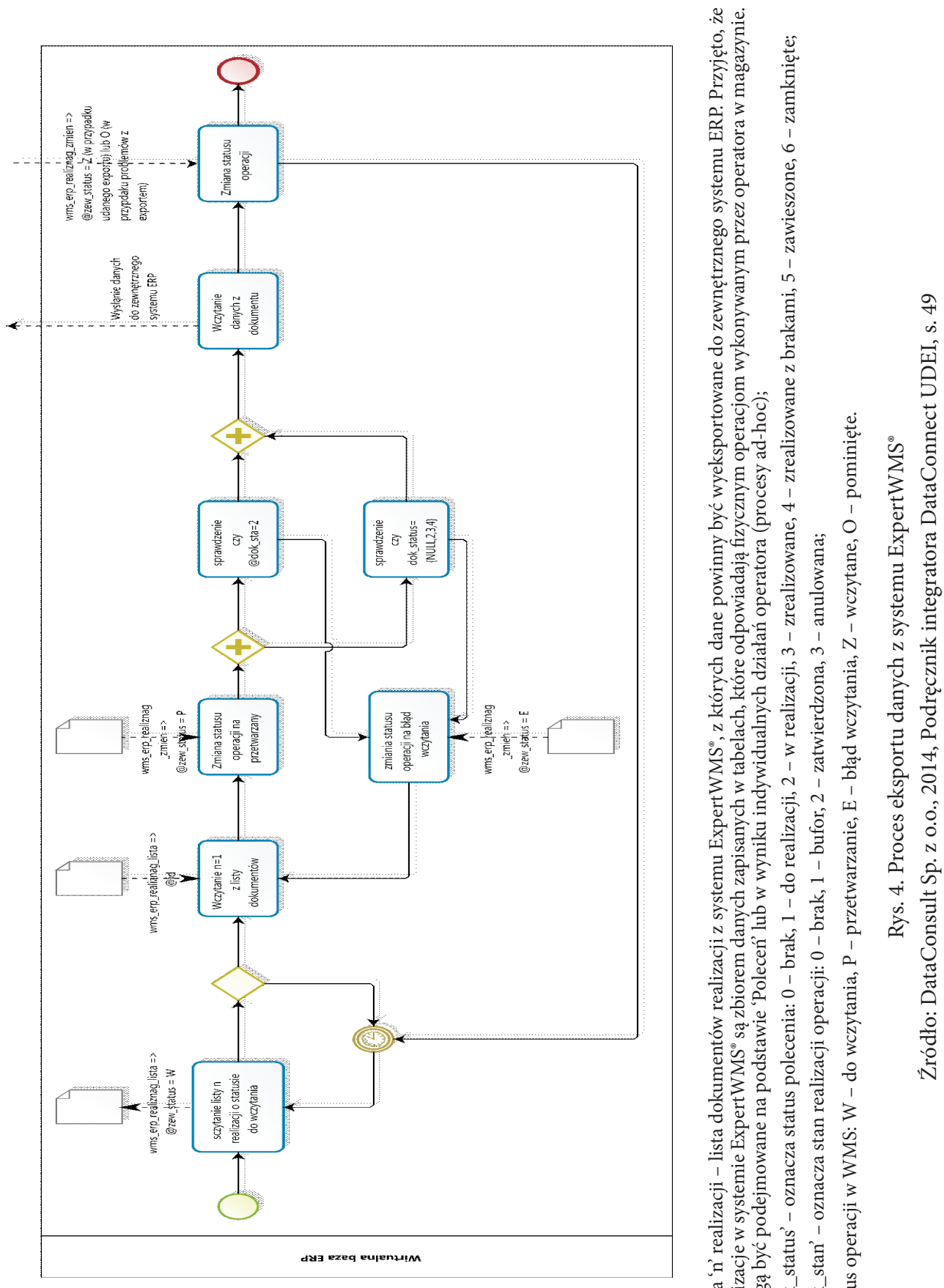


\section{Wnioski z badań}

System DataConnect dzięki swojej strukturze pozwala na integrację dowolnej liczby rożnych systemów. Zakłada konfigurację kanałów komunikacyjnych, zarządzania oraz informacji wymaganych do łączenia i przepływu danych z wybranym systemem. Został wyposażony w dwa mechanizmy komunikacji, tj. Dedykowany Protokół Wymiany Danych (DDEI) - zapewniający automatyczny import/export danych do określonego systemu zewnętrznego oraz Uniwersalny Protokół Wymiany Danych (UDEI) - umożliwiający automatyczny import/export danych do wirtualnego systemu, skąd następuje eksport z systemu ExpertWMS ${ }^{\circledast}$ do dowolnego systemu ERP dzięki zdefiniowanym regułom.

Biorąc pod uwagę cel badań rozwojowych, w artykule przedstawiono najpierw proces importu danych w mechanizmie UDEI, który jest realizowany za pomocą procedur dla operacji wykonywanych w systemie ExpertWMS ${ }^{\circledast}$. Testowanie procedur dla obiektów 'Magazyny', 'Towary', 'Kontrahenci, 'Słowniki' i 'Polecenia', odzwierciedlających procesy i dokumenty rzeczywiste w magazynie, nie wykazało błędów w realizacji poprawnego importu danych. Wprowadzone udoskonalenia dotyczyły możliwości utworzenia 'Polecenia' przy pomocy dodatkowej procedury, bez konieczności podawania identyfikatora kontrahenta. W tym celu przyjęto, że należy podać adres kontrahenta, korzystając z procedury 'dbo.wms_erp_kntadresy_add'. W przypadku procedury usunięcia 'Polecenia' identyfikacja może następować po typie i kodzie dokumentu. Analogiczna sytuacja wystąpiła dla procedury usuwania elementów 'Polecenia'.

W celu poprawnej komunikacji pomiędzy systemami należy aktualizować zewnętrzny system ERP o zmiany wprowadzone przez operatorów w trakcie pracy, dlatego proces eksportu danych z ExpertWMS ${ }^{\circledR}$ w systemie DataConnect dotyczy operacji na 'Poleceniach' i 'Realizacjach' (tj. zbiór danych zapisanych w tabelach, które odpowiadają fizycznym operacjom wykonywanym przez operatora). Testy procesu eksportu omówionego szczegółowo w pkt. 2.3 wykazały poprawność funkcjonowania procedur. Okazało się, że jedynie w procedurze szczegółowej 'zwrot listy elementów poleceń według ustawionych filtrów’ musi być wstawiona jedna z podanych wartości, tj. typ obiektu, kod obiektu lub typ towaru, aby została zrealizowana poprawnie.

\section{Podsumowanie}

Wyzwania, jakie stawiane są przed systemami wymiany danych w przedsiębiorstwach produkcyjnych, które mają zapewnić niezawodny i szybki przepływ danych między systemami produkcji, logistyki magazynowej oraz zarządzania typu ERP, są kluczowe w świetle zagwarantowania stabilności i bezpieczeństwa produkcji, efektywności procesów w intralogistycznym łańcuchu dostaw. 
W artykule przedstawiono rozwiązania dotyczące procesów importu i eksportu danych 'do' i 'z' systemów ExpertWMS oraz ERP. Omówiono zasady i sposób działania mechanizmu komunikacji UDEI systemu DataConnect, który jest rezultatem przeprowadzonych prac rozwojowych przez firmę DataConsult w ramach projektu dotyczącego stworzenia odpornego na zaburzenia elektromagnetyczne systemu punktów pomiarowych przy gniazdach produkcyjnych opartego o technologię selektywnej bramki RFID.

\section{BIBLIOGRAFIA}

[1] Arenas M., Barcelo P., Libkin L., Murlak F., 2010, Relational and XML Data Exchange, Morgan \& Claypool Publisher, USA.

[2] BRdulaK H., 2011, Logistyka w trudnych czasach - szansa czy ryzyko? Zmiany w globalnych łańcuchach dostaw, [w:] H. Brdulak (red.), Logistyka przyszłości, Polskie Wydawnictwo Ekonomiczne, Warszawa.

[3] Bussler CH., 2003, B2B Integration: Concepts and Architecture, Springer Science \& Business Media, Berlin.

[4] Dataconsult Sp. z o.o., 2014, Podręcznik integratora DataConnect UDEI, Kraków.

[5] Dataconsult Sp. z o.o., 2013, Odporny na zaburzenia elektromagnetyczne prototyp systemu punktów pomiarowych przy gniazdach produkcyjnych oparty o technologię selektywnej bramki RFID, Raport z badań, Kraków.

[6] Doan A., Halevy A., Ives Z., 2015, Principles of Data Integration, Elsevier \& Morgan Kaufmann, USA.

[7] Fowler M., 2005, Architektura systemów zarządzania przedsiębiorstwem. Wzorce projektowe, Wyd. Helion, Gliwice.

[8] JuRga A., SŁAWIŃsKa M., 2011, Wybrane aspekty projektowania systemów informacyjnych wspomagających procesy logistyczne, „Gospodarka Materiałowa i Logistyka”, nr 11.

[9] KLonowski J.Z., 2004, Systemy informatyczne zarzadzania przedsiębiorstwem. Modele rozwoju i właściwości funkcjonalne, Oficyna Wydawnicza Politechniki Wrocławskiej, Wrocław.

[10] Kwiecień R., 2012, Komputerowe systemy automatyki przemysłowej, Wyd. Helion, Gliwice.

[11] Linthicum D., 2001, B2B Integration Application, Reading MA, Addison Wesley, USA.

[12] Łobaziewicz M., SieczKarek K., Maćкowiak A., 2013, Concept of Resistant to Electromagnetic Disturbances Prototype of Measuring Points System Located in Production Cells Based on RFID Selective Gate Technology, "International Journal of Computer \& Information Technologies", No. 2 (1).

[13] Łobaziewicz M., Maćкоwiak A., SieczKarek K., 2014, Koncepcja odpornego na zaburzenia elektromagnetyczne prototypu systemu punktów pomiarowych przy gniazdach produkcyjnych opartego o technologię selektywnej bramki RFID, „Logistyka”, nr 3.

[14] MaćKowiak A., Sieczkarek K., Łobaziewicz M., 2014a, Możliwość zastosowania materiałów absorbcyjnych do eliminacji zakłóceń w pracy systemów automatycznej identyfikacji w oparciu o fale radiowe RFID, „Logistyka”, nr 4.

[15] Maćкоwiak A., SieczKarek K., Łobaziewicz M., 2014b, Możliwość zastosowania materiałów absorpcyjnych EMC do eliminacji zakłóceń w pracy radiowych systemów komunikacyjnych, „Przegląd elektrotechniczny", nr 8. 
[16] Morris H.D., 2016, IDC's Worldwide Software Taxonomy, IDC Analyse the Future, USA.

[17] Nicolescu V., Wittges H., Krcmar H., 2006, New Directions in SAP R/3: Services Oriented Architecture, (SOA) and Netweaver, [in:] Ch.S. Sankar, K.H. Rau (eds.), Implementation Strategies for SAP R/3 in a Multinational Organization: Lessons from a Real-World Case Study, IGI Global, USA.

[18] Ning Q., Wang T., JiAng L.L.Y., 2012, Research on CNC Machine Tools Integration Condition Monitoring System and Its Information Exchange Technology, [in:] Y. Zhang (ed.), Future Wireless Networks and Information Systems, Lecture Notes Electrical Engineering, Springer-Verlag GmbH Berlin Heidelberg, Vol. 144.

[19] Tundys B., Sowa M., 2010, Wplyw informatycznego wsparcia procesów logistycznych na konkurencyjność łańcucha dostaw, [w:] M. Chaberek, A. Jezierski (red.), Informatyczne narzędzia procesów logistycznych, Wydawnictwo CeDeWu, Warszawa.

[20] Wing L., Shankararaman V., 2007, Enterprise Architecture and Integration: Methods, Implementation and Technologies, Idea Group Inc., New York.

[21] Yang T., Fei M., Xue D., Tan Y., Zhou X., 2006, A Proposed Case Study for Network Control Systems, [in:] D. Huang, G.W. Irwin (eds.), Proceedings of Computational Intelligence, International Conference on Intelligent Computing, Springer Verlag, Part 2.

\section{NETOGRAFIA}

[1] Dhanda P., Sharma N., 2016, Extract Transform Load Data with ETL Tools, International Journal of Advanced Research in Computer Science, No. 3 (7), www.ijarcs.info (05.06 2016).

[2] Liu Y., Wu L., Cheng G., 2010, A remote Fault Diagnosis System of NC Machine Tool's Spindle based on B/S Model, "Equipment Manufacturing Technology", No. 4, http://en.cnki.com.cn/ Article_en/CJFDTOTAL-GXJX201004045.htm (04.2010).

[3] ŁobazIewicz M., 2017, Communication Model of Measuring Points Using a RFID Gate In Production Logistics, [in:] Research in Logistics\&Production, No. 4 (7), Publishing House of Poznan University of Technology, Poznań, www.research.logistyka-produkcja.pl (30.08.2017).

[4] Ronanki R., Verma A., Pierce D., Shilling M., 2016, Industrialized Analytics, [in:] Tech Trends 2016: Innovating in the digital era, Deloite University Press, https://www2.deloitte.com/ content/dam/Deloitte/nl/Documents/technology/deloitte-nl-technology-tech-trends-2016.pdf (3.08.2016).

[5] Tyagi H., Watanabe S., 2017, Universal Multiparty Data Exchange and Secret Key Agreement, Cornell University Library, https://arxiv.org/abs/1605.01033 (15.01.2017). 